\title{
18. OLIGOCENE-MIOCENE BIVALVE MOLLUSCA AND OTHER MACROFOSSILS FROM SITES 270 AND 272 (ROSS SEA), DSDP, LEG 28
}

\author{
R.K. Dell, National Museum, Wellington, New Zealand \\ and \\ C.A. Fleming, New Zealand Geological Survey, Lower Hutt, New Zealand
}

\section{INTRODUCTION}

Macrofossils from the mid Tertiary sediments sampled at Sites 270 and 272 are the first direct evidence of the Miocene history of the Antarctic benthos and also throw light on the paleogeography of the Ross Sea in Oligocene-early Miocene time. The specimens reported here were segregated on shipboard by Dr. P.J. Barrett, Victoria University, New Zealand, and passed to the writers for this report.

Site $270\left(77^{\circ} 26.48^{\prime} \mathrm{S}, 178^{\circ} 30.19^{\prime} \mathrm{W}\right)$ was drilled in 634 meters of water, with a total penetration of 422.5 meters. Site 272, which produced fewer macrofossils, was drilled 443 meters in a water depth of 629 meters at $77^{\circ} 07.62^{\prime} \mathrm{S}$, $176^{\circ} 45.61^{\prime} \mathrm{W}$ (see Figure 1). A general account of the results of Leg 28 has been published (Hayes, Frakes, et al., 1973). A summary of the log at Site 270, showing stratigraphic units and lithology, is shown in Figure 2.

\section{MATERIAL}

The material consists of 42 pieces of core from Site 270 and 4 from Site 272, on each of which one or more macrofossils are exposed, generally on the broken end of the core, but in some cores as cross-sections cut by the bit. Some of the fossils are complete and well preserved, but others show evidence of varying amounts of breakage and wear before burial. Thus some bivalves have the valves articulated, but some have the valves displaced by postmortem transport within the sediment; some are single valves variously worn, and others are fragments of valves broken and abraded before burial.

Shell preservation varies independently. Some are well preserved and little altered, but others are chalky and tend to fracture through the shell more readily than they part from the matrix. Some bivalves have been crushed, presumably during mass transport of the sediment and not by load or by tectonic deformation. A few individual bivalves with valves articulated have pyrite deposited in the enclosed matrix, perhaps formed in reducing conditions caused by a decaying animal.

The following indicates the proportions of the main taxonomic groups in the collections:

\begin{tabular}{lcccc}
\hline & Site 270 & Site 272 & Total & Percent \\
\hline Polychaeta & 7 & 1 & 8 & 13.3 \\
Mollusca & & & & \\
$\quad$ Bivalvia & 36 & 4 & 40 & 66.7 \\
$\quad$ Gastropoda & 5 & 0 & 5 & 8.3 \\
Bryozoa & 2 & 0 & 2 & 3.3 \\
Indeterminable & 5 & 0 & 5 & 8.3 \\
\hline
\end{tabular}

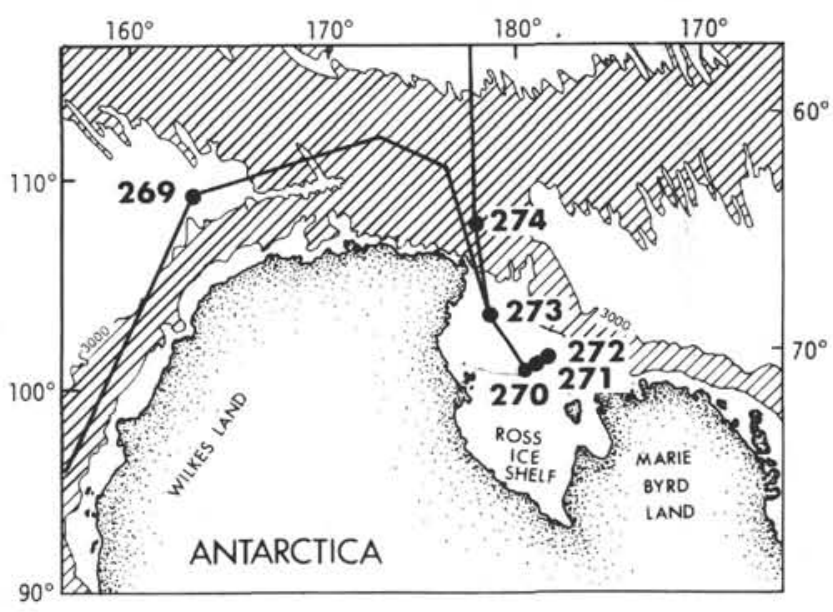

Figure 1. Sketch map showing Deep Sea Drilling Project Sites 270 and 272 and adjacent sites, and cross-section illustrating stratigraphic correlation (from Hayes, Frakes, et al., 1973).

\section{FAUNAL LIST AND TAXONOMIC NOTES}

Phylum MOLLUSCA
Class GASTROPODA
Family TROCHIDAE

One specimen, in hard siltstone cut vertically by the drill, shows the outline of a small rather solid trochiform gastropod, $9 \mathrm{~mm}$ high with the shell extensively recrystallized. The intersected whorls are empty of sediment. Efforts to expose the surface sculpture were unsuccessful. Sample 270-6-2, 43-45 cm.

Many Trochidae of varying ecology are known from Antarctic seas today (Powell, 1960).

\section{Family NATICIDAE \\ Amauropsis (?) sp.}

A small rather erect naticid with strong spiral sculpture more like the New Zealand Paleocene Amauropsona major (Marshall) than the Recent Antarctic and Subantarctic Amauropsis (of which there are 10 species; Powell, 1960; Dell, 1973). Sample 270-14, CC.

A cross-section in hard matrix (Sample 270-38-4, 26-29 cm) shows a rapidly expanding logarithmic spiral and is perhaps another naticid, but with a much thinner shell than Amauropsis.

Both specimens of Nuculana $\mathrm{cf}$. inaequisculpta show naticid borings near the umbones.

\section{Family BUCCINULIDAE \\ Proneptunea n. sp. aff. duplicarinata Powell (Plate 1, Figure 1)}

1951 Proneptunea duplicarinata Powell, Discovery Reports 26, p. 50, pl. 6 , fig. 13. 


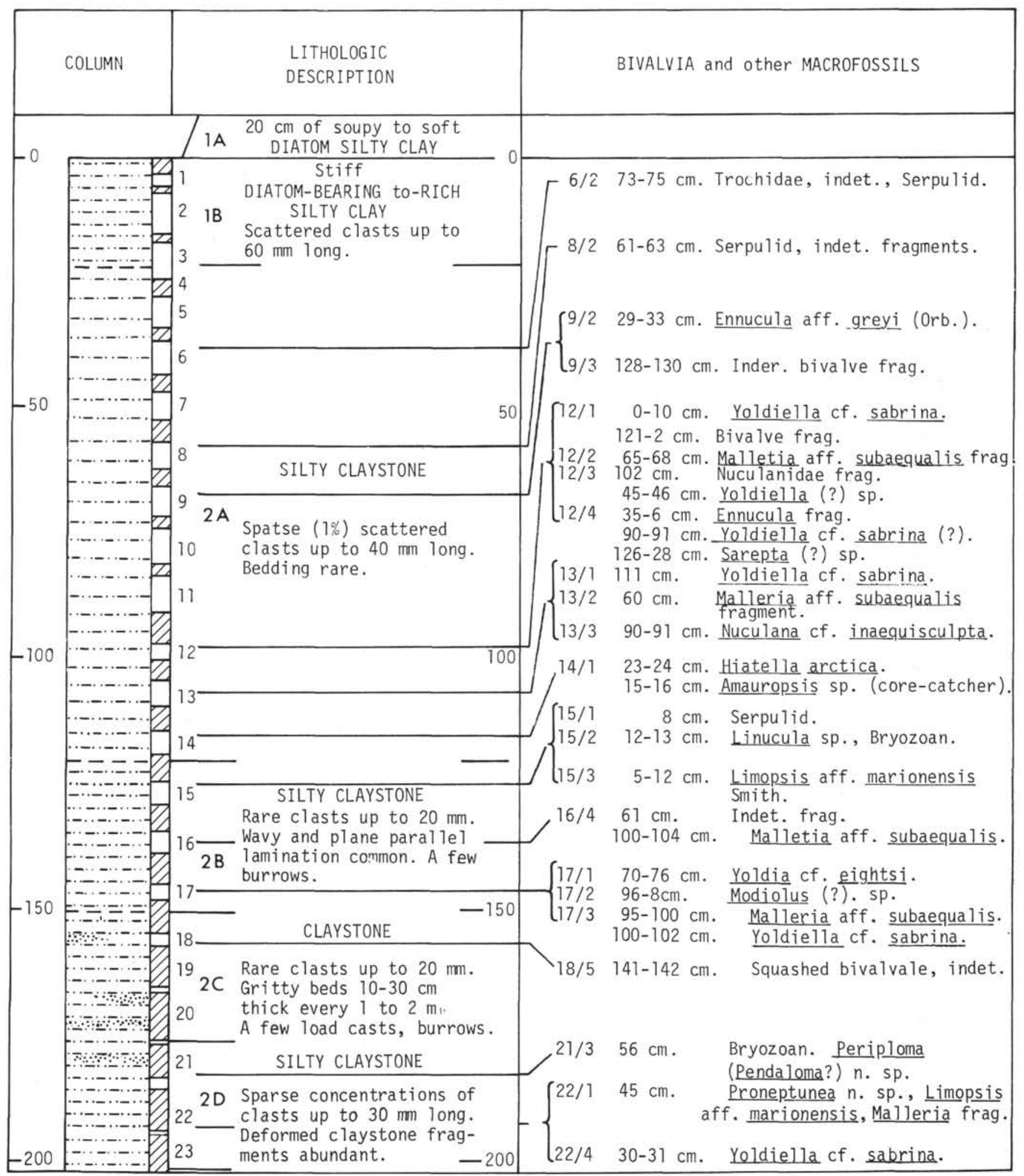

Figure 2. Stratigraphic distribution of macrofossils, Site 270.

A poorly preserved siphonostomatous gastropod with a body whorl $31 / 2$ times as high as the spire, with strong rather flat spiral ribs below the periphery, crossed by incremental lamellae. Two close-set raised spiral lamellae separated by a narrow groove form a carina on the periphery of the whorls. Height $9 \mathrm{~mm}$. Sample 270-22-1, $45 \mathrm{~cm}$.
The specimen is fragmentary but is sufficiently close in style and sculpture, especially in the double peripheral carina, to suggest that it is correctly placed in this endemic Subantarctic genus. Of the three species known (amabilis Thiele, Kerguelen; fenestrata Powell, South Georgia; duplicarinata Powell, between South Georgia and Shag 


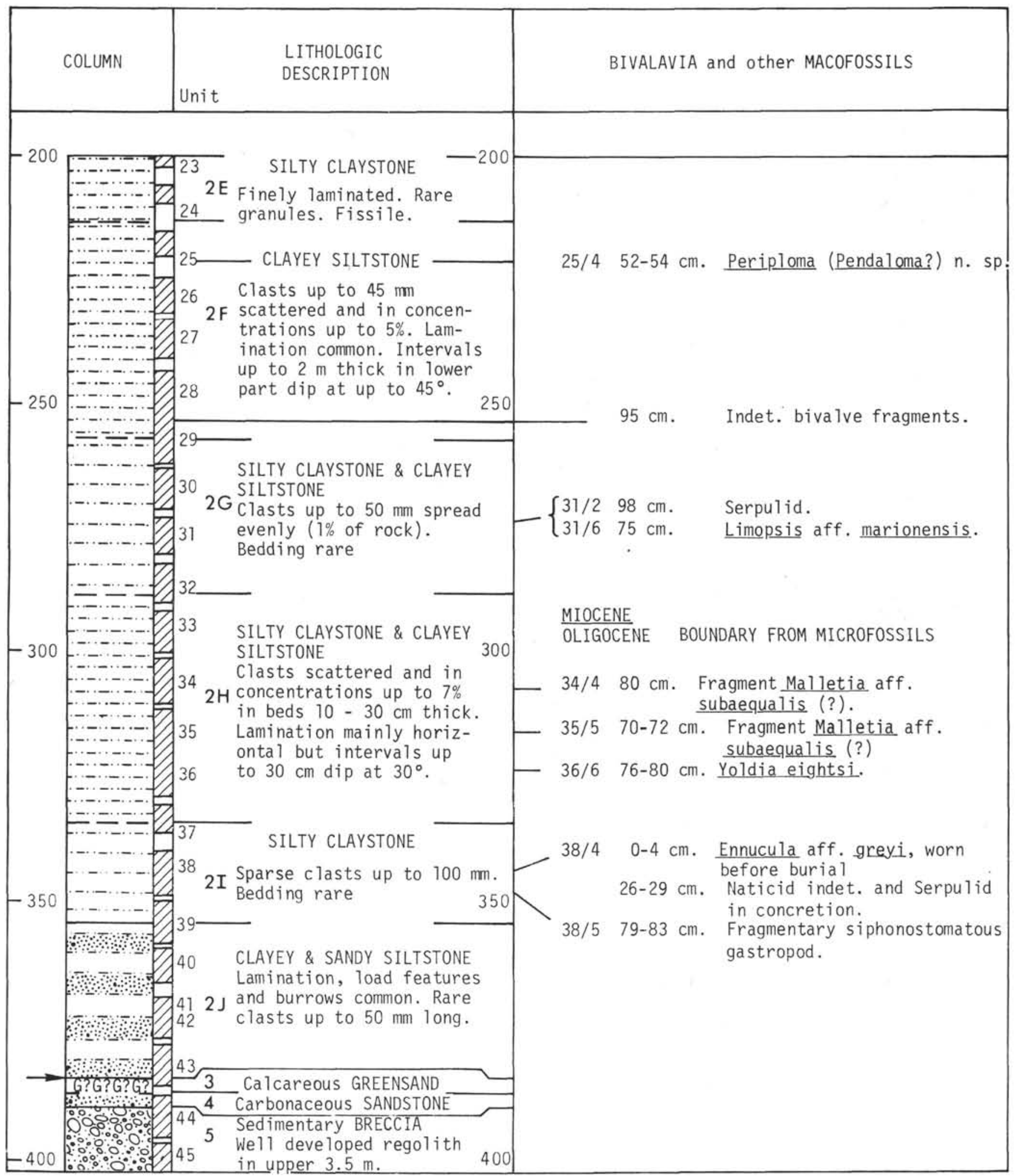

Figure 2. (Continued).

Rocks), the species is closest to the last, and in particular to its penultimate whorl, before the development of double keels on spirals below the periphery.

The Recent species occur in shallow shelf waters, down to 177 meters.
A further siphonostomatous gastropod, incomplete and crushed, is present in Sample $270-38-5,78-83 \mathrm{~cm}$. The body whorl has a peripheral carina, the spire is low, the suture is at the carina, the columella and posterior siphon are long and twisted. It has not been identified more precisely. 


\section{Class BIVALVIA \\ Family NUCULIDAE \\ Linucula sp.}

Sample 270-15-2, 12-13 cm. An internal mold about $6 \mathrm{~mm}$ long of a left valve, showing crenulated margin, and fragments showing external radials crossing concentric folds. Linucula is absent from the Antarctic benthos but present in the living Subantarctic fauna and in the Miocene to Recent faunas of New Zealand. Species of Linucula extend from the shelf to depths of 330 fathoms $(600 \mathrm{~m})$ on the slope.

\section{Ennucula ? aff. grayi (d'Orbigny)}

(Plate 1, Figure 3)

1964 Ennucula grayi d'Orbigny; Dell, Discovery Reports 33, p. 142, pl. 2, fig. 3-6.

A large thick-shelled Ennucula occurs at both Sites 270 and 272 in five cores, but few specimens are complete enough for specific comparison. Right valves from Samples 272-25-2, $63 \mathrm{~cm}$ and 270-38-4, 0-4 $\mathrm{cm}$ resemble $E$. grayi in outline, but the former is considerably larger than the largest specimen measured by Dell (1964). The best (but incomplete) specimen, from Site 272 is $23 \mathrm{~mm}$ long and must have exceeded $28 \mathrm{~mm}$ when complete. The Antarctic Miocene species is thus as large as the largest examples in this worldwide genus known to the writers, notably $E$. cumingi Hinds $(28.0 \mathrm{~mm})$ and $E$. cf. superba (Hedley) (just under $28 \mathrm{~mm}$ ).

Ennucula grayi and its close relative $E$. puelcha live on the shelf of South America and the Falkland Islands, the deepest record seen being a specimen from 329 fathoms $(600 \mathrm{~m})$, Magellan Strait (Dell, 1964), which was most likely transported from shallower depths. The smaller New Zealand shelf species E. strangei also occurs in about 600 meters off the shelf edge. Other thick-shelled Ennucula occur in shallow sediments in the Pliocene and off the modern coasts of Australia. Thin-shelled specimens occur in abyssal depths (E. panamina [Dall], see Knudsen, 1970). The specimen from Sample 270-25-2 has been abraded before burial.

\section{Family NUCULANIDAE}

Nuculana (s.l.) cf. inaequisculpta (Lamy)

1964 Nuculana (s.l.) inaequisculpta (Lamy) Dell; Discovery Reports 33, p. 144.

Two incomplete individuals with the valves closed. The shell is fairly solid and inflated, the proportions, length:height:inflation being 10:5.8:4.4. They are porcellanous, like a Nuculana, and thus differ from most Malletiidae which tend to be chalky, but the hinges cannot be studied as the valves are articulated in both specimens. Sculpture of fairly regular concentric striae is typical of $N$. inaequisculpta. More inflated and more regularly sculptured than $N$. sabrina. Length 9 , height 5.2 , inflation $4 \mathrm{~mm}$. Samples 270-13-3, 90-91 cm; 14-1, $127 \mathrm{~cm}$.

Both specimens have a Naticid drill hole penetrating one valve near the umbo.

$N$. inaequisculpta is known from the South Orkneys, South Shetlands, South Georgia, and the Palmer Archipelago in depths of 75 to 244-344 meters (Dell, 1964; Soot-Ryen, 1951), but not from the remaining sectors of the Southern Ocean.

\section{Yoldiella cf. sabrina (Hedley)}

1972 Yoldiella sabrina (Hedley); Dell, Rec. Dominion Museum 8 (3): 24 , Figs. 8,9

Three specimens, two with both valves, and a number of pieces of small thin-shelled taxodont bivalves with rounded-quadrate outline. Among living Antarctic and Subantarctic species they have most of the features of Yoldiella sabrina (Hedley) and Y. chilenica Dall (see Dell 1972) but none of the interiors prepared show the characters of the hinge and ligament well enough to determine the group accurately. They also superficially resemble species of Minormalletia (Malletiidae) from off Acapulco and from the New Zealand Cenozoic. Length 13, height $8 \mathrm{~mm}$. (Site $27013-1,111 \mathrm{~cm}$ ). Site $270-21-1,0-10 \mathrm{~cm} ; 12-4,90$ $91 \mathrm{~cm} ; 13-1,111 \mathrm{~cm} ; 15-1,15-16 \mathrm{~cm} ; 17-3,100-102 \mathrm{~cm} ; 22-4,30-31 \mathrm{~cm}$.

Yoldiella sabrina still occurs in the Ross Sea and is at least partially circumantarctic, living in depths of 12 to $836 \mathrm{~m}$.

\section{Yoldiella (?) sp.}

Site $270-12-3,45-46 \mathrm{~cm}$. Imprint of left valve exterior, two fragments of shell, obscure imprint of right valve of same individual. Length 6.6 $\mathrm{mm}$, height $3.8 \mathrm{~mm}$.
The hinge imprint suggests that the anterior and posterior series of chevron-shaped teeth are separated but does not clearly show the chondrophore, so that family and generic placing are not quite certain. The rostrum has the characteristic rostral flexure of Yoldiella and is better defined than in the Malletiids Saturnia or Neilonella. In shape, the shell is very similar to Tindaria thea Dall, figured by Knudsen (1970, pl. III, fig. 9) from 2000 meters in the eastern Pacific Ocean (Albatross Station 4564), and also quite close to Yoldiella valettii (Lamy) but the Miocene fossil is much larger than the latter.

A very imperfect left valve from the same core $(12-3,105 \mathrm{~cm})$ is probably a different species of Nuculanid but its condition does not permit closer identification.

\section{Yoldia (Aequiyoldia) eightsi (Couthouy)}

1964 Dell; Discovery Reports 33, p. 146, pl. 2, fig. 11.

Two individuals, one (36-6) with valves displaced and fractured by compression so that the hinge of the right valve could be developed to show an opisthodetic ligament above the anterior end of the posterior tooth series. The shell is evenly rounded in front and does not show the shallow sulcus present in the larger species of Malletia present in the cores. The second specimen $(17-1)$ is closely similar, the third $(17-3)$ only an anterior fragment. Comparison with Recent specimens of $Y$. eightsi shows no elements of difference in what remains of the hinge. Sample 270-36-6, 76-80 cm. Length 22 (estimated), height $12 \mathrm{~mm}$. Sample $270-17-1,70-76 \mathrm{~cm}$. Length 18.5 , height $11 \mathrm{~mm}$. This shell closely resembles the living circumantarctic Yoldia (Aequiyoldia) eightsi (Couthouy) which occurs in shallow water (5-75 m, Nicol, 1966) rarely in 728 meters (Dell, 1964).

Yoldia sp.

(Plate 1, Figure 2)

A well-preserved left valve, quite closely resembling the Boreal species $Y$. hyperborea (Torell) in shape, with smooth shell, subcentral low beak, and narrowly rounded anterior and posterior ends, the latter slightly narrower but not carinate or rostrate. The only Antarctic species with this general shape is Yoldiella oblonga Pelseneer which, however, is much smaller. The taxodont hinge has a wide shallow resilium between anterior and posterior series. Length 13.2, height 7.8 $\mathrm{mm}$. Sample 272-23-3, 147-156 cm.

\section{cf. Ledella (?) sp.}

A chalky left valve lacking all exterior surface with the beak missing. The shell seems to have been fairly solid and to have had a weak sinus below the ill-defined beak. Sample 272-44-1, $77 \mathrm{~cm}$. Length 5.7 , height $4.5 \mathrm{~mm}$.

\section{Sarepta sp.}

A fragment of a valve with slight inflation, low beaks, and smooth surface with a rather straight-hinge line interrupted by a triangular chondrophore; anterior tooth series crowded, posterior series of nine teeth occupying only portion of hinge. Length estimated as 14 , height as $8 \mathrm{~mm}$. Sample $270-12-4,126-128 \mathrm{~cm}$.

\section{Family MALLETIIDAE}

\section{Malletia aff. subaequalis Sowerby}

(Plate 1, Figures 4, 5)

1964 Dell; Discovery Reports 33, p. 148, pl. 2, fig. 10.

The largest bivalves at Site 270 seem to represent a species of Malletia related to several species now living on the shelf of South America, Falkland Islands, Kerguelen, and the Antarctic continent. It has a weak narrowly rounded posterior rostrum on the ventral side of which the growth lines are straight or even slightly concave, forming a weak sulcus such as characterizes most of the living species.

From the DSDP specimen from Sample 270-16-4, 102-104 cm, part of the hinge was exposed showing the ligament above the posterior series of teeth. One of two specimens in 17-3 shows a pallial sinus closely matching that of a specimen of $M$. gigantea (Smith), Kerguelen. The species is more elongate than $M$. gigantea and $M$. subaequalis, but is undoubtedly related to them. Length 30.5 , height 16.6 mm (largest specimen from 17-3).

Fragments referred to this species, some of them broken before burial, occur in Samples 34-4, $80 \mathrm{~cm}$; 35-5, 70-72 cm.

The Subantarctic species of Malletia which seem related to these DSDP specimens range from depths of 12 meters or less to 271 meters, 
i.e., they live chiefly on the continental shelf. Malletia subaequalis ranges from Rio de Janeiro to Argentina.

\section{Family LIMOPSIDAE}

\section{Limopsis aff. marionensis Smith}

1964 Dell; Discovery Reports 33, p. 152, pl. 3, fig. 6-14; pl. 4, fig. 1, 2. Sample 270-15-3, 5-12 cm; 22-1-45 (fragment); 31-6, $7.5 \mathrm{~cm}$ (broken juvenile).

The best specimen (15-3) is a left valve $22 \mathrm{~mm}$ in length, more quadrangular than giant obliquely elongated adults. Fragments of an articulated pair of valves (22-1) are judged to have been from a more oblique individual about $50 \times 42.5 \mathrm{~mm}$. Finally, 31-6 was a fresh unworn juvenile (articulated valves) about $10 \mathrm{~mm}$ high but is badly broken. The larger specimens agree well in sculpture with Recent specimens of $L$. marionensis from off Enderby Land; on the juvenile the radials cross the concentric folds to produce regular low cusps. The series can be matched in size and shape by Recent specimens.

In Core 31, Section 6, the ventral margin of the closed juvenile was closely applied to an irregular rock clast suggesting that it may have been attached to the rock by its byssus.

Limopsis marionensis is one of the most far-ranging of all Antarctic bivalves, being circumpolar from lat $74^{\circ} 46^{\prime} \mathrm{S}$ in the Ross Sea north to the Indian Ocean Subantarctic Islands, Falkland Islands, and the Chilean coast to just beyond $42^{\circ} \mathrm{S}$. It occurs in depths of 56 to 1097 meters (those in $393 \mathrm{~m}$ being alive) and generally in deeper water than the other Antarctic species L. lilliei Smith (Nicol, 1966). Nicol reports that specimens from Deepfreeze Expeditions were from hard rocky bottom, hard gravelly bottom with coral, and sandy bottom. The three records from Site 270 are in mudstone and diamictite and were thus probably transported from their normal habitat without separation of the valves, i.e., probably by gravity slide or turbidity current.

\section{Family MYTILIDAE \\ ?Modiolus (s. lat.) sp.}

Ventral fragments (up to $21 \times 12 \mathrm{~mm}$ ) of the two valves of the thin irridescent nacreous shell of a Modiolus (or perhaps a related smooth genus such as Mytella, Amygdalum, or a large Lithophaga). The interior ventral margin has a narrow marginal bevel representing the limits of reflexed periostracum. The interior is smooth but with microscopic radial striae (as in some Modiolus spp.) Exterior with irregular weak concentric folds.

No mytilids of this group live in the Antarctic today and even in Subantarctic seas there are few candidates for relationship with these fossils judged by the list of Powell (1960). The surface texture seems to rule out Mytilus, Perna, and Choromytilus, leaving Lithophaga patagonicus (d'Orbigny) as the only species listed by Powell smooth enough for consideration. Modiolus and Mytella do not occur commonly if at all in southern Chile today (Soot-Ryen, 1955) although related species were present there in the Pliocene (Watters and Fleming, 1972).

\section{Family PECTINIDAE}

\section{Chlamys (sensu lato) n. sp. aff. natans (Philippi)}

(Plate 1, Figure 6)

1971 Semipallium (Juxtamusium) natans (Phil.); Dell, Records Dominion Museum 7, p. 169

Sample 272-33-2 (Top) Unit 2B.

The external and internal imprint of a single valve, believed to be a left valve, was pried apart by a spatula during shipboard subdivision of Core 33. No trace of shell material is present, suggesting that it was membranous (as natans) and had been dissolved during early diagenesis. The fossil agrees with natans in shape, the general nature of its external and internal radial ribbing and in the concentric striae that cross them, differing in the following ways (left valve alone compared). The shell appears to have been somewhat broader (in relation to height), the radial ribs are fewer and thus have wider interspaces. As in natans, the primary ribs, about $10 \mathrm{~mm}$ from the beak (18 in natans, estimated 16 in 21-3) increase by intercalation of secondary ribs to a total of about 40 in natans, and no more than 30 in the Miocene fossil, perhaps mainly because the posterior flank (which has weaker ribbing in natans) is smooth in the fossil. No oblique Camptonectes striations are preserved on the fossil. Despite these differences, the relationship to a most distinctive pectinid is quite clear. Length 25.7 , height (estimated) $31 \mathrm{~mm}$.
Grau (1959) placed Pecten natans in Juxtamusium Iredale, but Waller (1972, p. 252) has shown that this Fuegian species differs in resilium, ctenolium, and sculpture from Juxtamusium oblectatum Iredale, type of Juxtamusium, and from J. maldivensis (E.A. Smith). These are tropical Indo-Pacific forms whereas $P$. natans is subantarctic, ranging from $42^{\circ} \mathrm{S}$ to Tierra del Fuego and Magellan Straits living attached to the fronds or holdfasts of Macrocystis thus on shallow rocky shores (Dell, 1971; Grau, 1959 quoting King and Philippi). $P$. natans agrees with the subgenus Pacipecten Olsson (type: Pecten tumbezensis d'Orbigny, from Peru) in the shape of its ears, its triangular left valve ribs, dissimilar valve pigmentation, fine concentric striae, and west American distribution, but differs markedly in shape.

The natans stock has some characters in common with the distinctive living circumantarctic scallop Adamusium colbecki (Smith) but the differences outweigh the resemblances, and Adamusium remains without demonstrated derivation from any other pectinid.

\section{Family HIATELLIDAE}

Hiatella arctica (Linnaeus)

Sample 270-14-1, 23-24 cm.

A right valve broken before burial, but estimated to have been about $10 \mathrm{~mm}$ long, with the characteristic sculpture and hinge of $\mathrm{Hia}$ tella.

Recently authors have considered Northern and Southern Hemisphere shells cannot be separated (Dell, 1964; Beu, 1971). H. arctica is thus a bipolar (if not cosmopolitan) species and its occurrence in the Miocene of New Zealand and the Ross Sea shows that bipolarity at the level of species is not always due to Quaternary faunal migrations. It is a nestler, often in pholad borings, on hard bottom, generally in shallow water, but has been recorded in 620 meters (New Zealand, Dell, 1956). Probably it lives wherever the habitat is suitable and is not a reliable indicator of depth.

\section{Family PERIPLOMATIDAE \\ Periploma (Pendaloma?) n. sp. \\ (Plate 1, Figure 7)}

Sample 270-25-4, $52-54 \mathrm{~cm}, 21-3,56 \mathrm{~cm}$

A right valve, somewhat compressed, with the general outline of Chama praetenuis Pulteney, type of Bontaea Brown, but with a welldeveloped right valve chondrophore that indicates affinity with Periploma rather than Bontaea. Shell weakly inflated, longer than high, broadly rounded in front, truncated behind; poorly sculptured by concentric folds that become obsolete posteriorly; pallial sinus wide and shallow; chondrophore strong; posterior adductor scar well defined. The specimen from 21-3 is an external mold showing the posterior half of another right valve together with shell fragments. Length 15 , height $12 \mathrm{~mm}$.

Most species of Periploma live infaunally in fine-grained sediments in deep but not abyssal waters. P. macphersoni Marwick (1931), which ranges throughout the Miocene in deep-water mudstones in New Zealand, is more circular in outline, but an undescribed New Zealand species recorded from upper Miocene to lower Pleistocene (GS Localities 504, Mahia; 1215, Wairoa) and from Palliser Bay (Pliocene, Beu, 1967) is closely similar to the Ross Sea fossil. These are beds that were deposited in appreciable depths in rapidly sinking geocynclinal basins. Marwick (1965) considered the Wairoa beds were deposited in 180 to 500 meters, and Beu preferred a depth of between 400 and 600 meters for the Palliser Bay bathyal Pliocene. Atlantic species were described by Dall from 384 and 43 meters while the very large $P$. planiuscula (Sowerby) and P. (Halistrepta) sulcata Dall live shallow enough to be cast on California beaches. The only Australian Periploma is $P$. (Pendaloma) micans Hedley, from 82 meters off New South Wales, which may be quite closely related to the Ross Sea species, despite the presence of a radial groove to the posteriodorsal angle, in the holotype, that was the basis for Pendaloma Iredale.

No related forms are known today from Antarctic or Subantarctic seas.

\section{Phylum BRYOZOA}

Small fragments of Bryozoan colonies occur in Samples 270-15-2, $12-13 \mathrm{~cm}$ and $270-21-3,56 \mathrm{~cm}$. They seem clearly to have been transported into the sediments from a higher energy environment. 


\section{Phylum ANNELIDA}

\section{Class POLYCHAETIA}

\section{Family SERPULIDAE}

Short lengths of weakly tapering straight or gently curved calcareous worm tube, with a characteristic concentric lamellar ornament, occur at six horizons at Site 270: $6-2,43-45 \mathrm{~cm} ; 8-2,61-63 \mathrm{~cm}$; $15-1,8 \mathrm{~cm} ; 15-1,15-16 \mathrm{~cm} ; 31-2,98 \mathrm{~cm}$; and $38-4,26-29 \mathrm{~cm}$. A bundle of four tubes in $15-1,8 \mathrm{~cm}$, is visible in cross-section, the individual tubes compressed to an oval shape. Several other tubes are compressed, with a median crack where they have broken. In 15-1, 15-16 $\mathrm{cm}$, a juvenile tube ( $0.5 \mathrm{~mm}$ diameter) is attached to an adult that seems to have been free. A small concretion in 38-4, 26-29 cm has formed around two Serpula tubes that seem to arise from a naticid gastropod visible in cross-section on the other side of the concretion. The specimens all appear to be the same species and resemble the tubes of Serpula more than those of any other Serpulid genus known to the writers. Dr. H. Zibrowius, Universite d'Aix-Marseille, has examined a specimen but considers it to be unidentifiable, even genetically.

Serpulids require hard objects to settle on and generally thrive in a high-energy hard-bottom environment. They are thus likely to have been transported into the fine-grained sediments of the hole, and most have been broken into small fragments (about $10 \mathrm{~mm}$ ) before burial. The scarcity of hard-bottom epifauna in the cores suggests however, that the polychaetes may have settled on quite small patches of hard bottom, or even on large erratics that might project above the depositional surface long enough for attached organisms to grow to maturity.

\section{INDETERMINABLE FRAGMENTS}

Shell fragments, mostly Bivalvia, some of them apparently broken and worn before burial, at Samples 270$8-2,9-3,12-1,16-4$, and $28-3$ were not identified. A bivalve in 18-5 with concentric lamellae is probably an addition to the fauna of the site, but has been badly crushed so that diagnostic features cannot be determined.

\section{DISCUSSION}

\section{Stratigraphic Distribution}

The macrofossils from Site 270 all come from Unit 2. In Figure 2 they are tabulated against the stratigraphic column and lithological description. Assuming that sampling effort was at a uniform level, the tabulation shows a concentration between 100 and 160 meters, across the boundary between Subunit 2A (unstratified, little or no reworking) and Subunit 2B (some reworking from bottom currents). Every subunit produced at least one macrofossil. The distribution of specimens or fragments broken and/or worn before burial does not reflect, on the whole, the differences in reworking by currents that were inferred from lithology.

No systematic change in the faunas sampled at Site 270 can be established. The lowest macrofossil (in Unit $2 \mathrm{I}$ ) is a taxon (Ennucula aff. grayi) that occurs also at the top in Unit 2A. The same species of Serpulid is listed from 2A, 2B, and 2I and of Limopsis in 2B, 2D, and 2G; but identification is seldom confident enough to follow this type of analysis with other taxa.

From Site 272, macrofossils were recovered from only four horizons in Unit 2, and from only two subunits thereof. Ennucula aff. grayi (d'Orb.) occurs in Unit 2A in Sample 22-6, 88-92 cm and in Unit 2B in Sample 25-2, $63 \mathrm{~cm}$. Yoldia (?) sp. occurs in Core 23, Section 3 (Unit 2B), and Chlamys n. sp. aff. natans (Phil.) in the top of Core 33, Section 2 (Unit 2B).

\section{Biogeographic Relationships}

Of 17 genera or species listed, 9 no longer live in Antarctic seas and 1 (Hiatella arctica) only reaches $60^{\circ} \mathrm{S}$. Three genera no longer live in either Antarctic or Subantarctic seas (Ledella, Sarepta, Periploma), but only the last-named is identified with confidence. Proneptunea, Ennucula aff. grayi, Yoldia eightsi, Yoldiella cf. sabrina, Nuculana cf. inaequisculpta, Malletia aff. subaequalis, Limopsis marionensis, and Chlamys (s. l.) n. sp. aff. natans are all related to Fuegian (Magellanic) or Scotia Arc forms emphasizing that "the bulk of the southern high-latitude molluscan fauna could have been derived from the Americas" (Powell, 1951). None of the fossil taxa, except the cosmopolitan Hiatella arctica, could have been derived from the known Cenozoic fauna of New Zealand. on the other hand, it may be incorrect to conclude that the Antarctic fauna was derived from Subantarctic America now that southern cool-temperate elements are known to have lived in the Antarctic seas during the Miocene, for some of such elements have not been recorded in the fossil record of Chile and Argentina until post-Miocene times and may equally well be immigrants that came from the south as the climate cooled during Pleistocene times.

The rather small sample from the early Miocene molluscan fauna of Antarctica (17 taxa identified at generic level) includes three "elements." First there is a considerable element ( 7 taxa) that has persisted as a characteristic part of the modern fauna of Antarctica (Amauropsis, Nuculana cf. inaequisculpta, Yoldiella sabrina, Yoldiella sp., Yoldia eightsi, Yoldia sp., Limopsis aff. marionensis). The second element (5 taxa) includes predecessors of species from the Subantarctic coasts of South America and the Scotia Arc that no longer live in truly Antarctic seas: Proneptunea aff. duplicarinata, Linucula, Ennucula aff. grayi, Malletia aff. subaequalis, Chlamys n. sp. aff. natans, Hiatella arctica. The third element consists of genera that are widespread in temperate seas but not known from the American Subantarctic or Antarctic regions, cf. Ledella, Sarepta, ?Modiolus, and Periploma; but several of these are doubtfully identified. The absence, even in a small sample, of such characteristic Antarctic molluscs as Limatula (several species) and Cyclocardia is worth noting.

To judge from this scant evidence, some distinctive elements in the Antarctic fauna were already established there in the Tertiary (as postulated by Fell, 1961 for the distinctive Ophiuroid fauna), together with forms that have since been forced to retreat either to the Subantarctic waters of the Scotia Arc and Fuegia, or in some cases have even been restricted to temperate regions. To the nucleus of taxa with a Tertiary history in Antarctica there may have been added other taxa such as several species of Limatula that have no Tertiary record; this last inference is tenuous being based on negative evidence and inadequate samples.

There are no faunal links between the fossils here described and older Tertiary Antarctic faunas (from shallower facies) described by Wilckens (1911) from Seymour Island and Cockburn Island (Wilckens, 1924), and by Hertlein (1969) from Ross Island. 


\section{Paleoecology}

Since the macrofossil samples show no obvious segregation into two or more stratigraphic units of differing facies, they are considered together. The following list summarizes the bathymetric distribution of the identified taxa that can contribute to interpretation of the sedimentary environment.

\section{Macrofossils: Bathymetric and Geographic Distribution of Related Taxa}

TROCHACEA: The identification is too general to permit any ecological conclusions.

Amauropsis (?) sp. Bipolar; Antarctic-Subantarctic species 6 to 420 meters.

Proneptunea aff. duplicarinata Powell: Shelf, South Georgia and Kerguelen.

Linucula sp. Shelf to 600 meters; not now in Antarctic, but reaches the Falkland Islands.

Ennucula aff. grayi (d'Orb.). Shelf to 600 meters near slope. Subantarctic South America.

Nuculana cf. inaequisculpta (Lamy). Scotia Arc, South Georgia to Palmer Archipelago in 75 to 344 meters.

Yoldiella cf. sabrina (Hedley). Antarctic. 12 to 836 meters, related to $Y$. chilenica, Dall, Chile.

Yoldiella (?) sp. Shallow water to 545 meters in Southern Ocean but 10,000 meters in Philippine Trench.

Yoldia (Aequiyoldia) eightsi (Couthouy). 5 to 728 meters, circum Antarctic.

Yoldia sp. Genus, still in Antarctica, ranges to 8300 meters.

cf. Ledella (?) sp. Continental slope to below 5000 meters; not Antarctic.

Sarepta sp. Shelf to below 10,000 meters in Philippine Trench; not Antarctic.

Malletia aff. subaequalis Sowerby. Related species 12 to 271 meters on Subantarctic shelf and east coast South America.

Limopsis aff. marionensis. Smith. L. marionensis lives in Subantarctic and Antarctic seas, 56 to 1097 meters.

?Modiolus sp. No geographically close representatives; mostly shallow but one species is abyssal in the tropics.

Chlamys (s. l.) n. sp. aff. natans (Philippi). Closely related to Magellanic species living on shallow-water kelp.

Hiatella arctica (Linn.) A cosmopolitan nestler in borings, generally on the shelf, but known from 620 meters. Southernmost record $60^{\circ} \mathrm{S}$.

Periploma (Pendaloma?) n. sp. Related species from shelf to 384 meters. No Subantarctic or Antarctic species.

Ennucula aff. grayi, Malletia aff. subaequalis, and Chlamys n. sp. aff. natans and perhaps Hiatella arctica which no longer live in high-latitude Antarctic seas are evidence that Miocene conditions in the Ross Sea may have been similar to those off southern Chile today, i.e., Subantarctic, the Chlamys now being restricted to Tierra del Fuego and the coast of Chile north to $42^{\circ} \mathrm{S}$ lat in shallow waters. Some of the other fossils identified do not now live in Subantarctic seas at all (e.g., Periploma), so Miocene seas may have been even warmer than those of southern Chile, but the evidence for this is not overwhelming.
Most of the macrofossils are members of the infauna in soft-bottom sediments of a wide range of depths, from the continental shelf to slope or even to abyssal depths, but a few are more restricted, and some that have been recorded from considerable depths near the shelf were probably transported there from the shelf (e.g., thick-shelled Ennucula, Malletia aff. subaequalis). Worn broken fragments confirm that transport has taken place. The most restricted in bathymetric range is Chlamys n. sp. aff. natans which has only been recorded from the beach down to 18 meters. The Recent species lives swimming about or attached by byssus to the fronds and holdfasts of the giant kelp Macrocystis, fringing rocky coasts in shallow water, only (according to Philippi, quoted by Grau, 1959) in places "where the sea cannot possibly become turbulent." Thus this species (to which the fossil is closely related, beyond all reasonable doubt) indicates that sheltered ice-free kelpfringed rocky coasts bordered some parts of the Ross Sea during the deposition of Unit 2B in the Miocene. It is therefore unlikely that sea ice formed a continuous cover, even seasonally, although the low diversity of foraminifera in Unit $2 \mathrm{~B}$ is thought to reflect relatively cold conditions in this part of the middle Miocene. Even less likely, in the writers' opinion, is the possibility that a least bed 2B was deposited under an enlarged Ross ice shelf, although deposition of clasts from bergs derived from valley glaciers is quite compatible with our conclusions.

The large number of fragments that had been broken or worn before burial includes some of those probably transported from shelf environments (e.g., Ennucula, Malletia aff. subaequalis) but others are complete and/or unworn (e.g., Chlamys, Serpulid) so that transport into the sediment in which they were buried must sometimes have been accomplished without wear and tear, probably within a cushioning turbidity current or similar mass gravity movement of sediment. Transport by ice rafting seems less likely for such shells. When the probable shelf species are excluded, the remaining taxa have a rather wide bathymetric tolerance, but a situation in several hundred meters at the foot of the continental slope would satisfy their known requirements.

Arctic and Antarctic bivalves commonly carry a chitinous periostracum protecting the shell from solution. Near the umbones, especially in species of Yoldia and Malletia, the periostracum is often penetrated at discrete points allowing the formation of circular conical solution pits. Similar solution pits can be seen near the umbo of Yoldia sp. (Site 272, Core 23, Section 3) and Yoldia eightsi (Site 270, Core 17, Section 1). They occur on living bivalves in varying depths from Arctic seas south to Puget Sound $(37 \mathrm{~m})$ and in the Southern Ocean north to Kerguelen $(45 \mathrm{~m})$. Despite this evidpnce of acidity, the thickness and persistence of calcium carbonate shells throughout Unit 2 at the site of deposition indicate that the bottom waters above the site of deposition were above the carbonate compensation level.

\section{ACKNOWLEDGMENTS}

We are grateful to the National Science Foundation and the Deep Sea Drilling Project Curator for the opportunity to study 
this interesting material, which was given to us by Dr. Peter J. Barrett, Victoria University of Wellington, a member of the scientific staff of Glomar Challenger for Leg 28. We are grateful to A.G. Beu and P.A. Maxwell for their opinions on classification and to P.N. Webb for discussion. The photographs were taken by Mr. T.R. Ulyatt, National Museum, Wellington.

\section{REFERENCES}

Beu, A.G., 1967. Deep-water Pliocene mollusca from Palliser Bay, New Zealand: Roy Soc. New Zealand Geol.. Trans, v. 5 , p. $89-122$.

1971. New light on the variation and taxonomy of the bivalve Hiatella: New Zealand J. Geol. Geophys., v. 4, p. 64-66.

Dall, W.H., 1908. The mollusca and brachiopoda [Albatross Reports]: Mus. Comp. Zool. Harvard Coll. Bull., v. 43, p. 205-487.

Dell, R.K., 1956. The Archibenthal mollusca of New Zealand: Dom. Mus. (Wellington) Bull. 18. 1964. Antarctic and Subantarctic mollusca: Amphineura, Scaphapoda and Bivalvia: Discovery Rep. 33, p. 93 250.

1971. The marine mollusca of the Royal Society Expedition to southern Chile) Rec. Dominion Mus., v. 7, p. 155-233.

1972. Notes on nomenclature of some mollusca from Antarctica and Southern South America: Rec. Dom. Mus., v. 8, p. 21-42. 1-216.

1973. Antarctic benthos: Adv. Mar. Biol., v. 10, p.

Fell, H.B., 1961. The fauna of the Ross Sea Part I. Ophiuroidea: New Zealand Oceanogr. Inst. Mem. 18.

Grau, G., 1959. Pectinidae of the Eastern Pacific Allan Hancock Pacific Exped., 23, 308 p.

Hayes, D., Frakes, L.A., et al., 1973. Leg 28 deep-sea drilling in the Southern Ocean: Geotimes, v. 18, p. 19-24.
Hedley, C., 1916. Mollusca: Sci. rep. Australas. Antarct. Exped. 1911-14, ser. C. IV, pt. 1.

Hertlein, 1.G., 1969. Fossiliferous boulder of early Tertiary age from Ross Island, Antarctica: Antarctic J. U.S., v. 4, p. 199-200.

Knudsen, J., 1970. The systematics and biology of Abyssal and Hadal Bivalvia: Galathea Rep. 11.

Marwick, J., 1931. The Tertiary mollusca of the Gisborne District: New Zealand Geol. Surv. Pal. Bull. 13. 1965. Upper Cenozoic mollusca of Wairoa District, Hawke's Bay: New Zealand Geol. Surv. Pal. Bull. 39.

Nicol, D., 1966. Descriptions, ecology and geographic distribution of some Antarctic pelecypods: Am. Paleont. Bull., 51.

Powell, A.W.B., 1951. Antarctic and Subantarctic mollusca: Pelecypoda and Gastropoda: Discovery Rep. 26, p. 47-196.

1960. Antarctic and Subantarctic mollusca: Rec. Auck. Inst. Mus. 5, p. 117-193.

Soot-Ryen, T., 1951. Antarctic Pelecypods: Sci. Rec. Norveg. Antarctic Exped. 1927-28 et sqq, 32.

, 1955: a report on the Family Mytilidae (Pelecypoda): Allan Hancock Pacific Exped., v. 20, p. 1175.

Waller, T.R., 1972. The Pectinidae (Mollusca: Bivalvia) of Eniwetok Atoll, Marshall Islands: The Veliger, v. 14, p. 221-264.

Watters, W.A. and Fleming, C.A., 1972. Contributions to the geology and palaeontology of Chiloe Island, southern Chile: Phil. Trans. Roy. Soc. Lond., ser. B, v. 263, p. 369408.

Wilckens, O. 1911. Die Mollusken der Antarktischen Tertiarformation: Swed. Sudpolar-Exped. 1901-1903, Wissenschaftl. Ergebn., v. 3, p. 1-42.

, 1924. Die Tertiare Fauna der Cockburn-insel (West-antarktika): Swed. Sudpolar-Exped. 1901-1903, Wissenschaftl. Ergebn., v. 1, p. 1-18. 



\section{PLATE 1}

Oligocene-Miocene mollusca from Sites 270 and 272 (Ross Sea).

Figure $1 \quad$ Proneptunea n. sp. aff. duplicarina.Powell. Sample 270-22-1, $45 \mathrm{~cm} .10 \times 5 \mathrm{~mm}$. (C.A.F. del.)

Figure $2 \quad$ Yoldia $\mathrm{sp}$.

Sample 272-23-3, $147-156 \mathrm{~cm} .13 .2 \times 7.8 \mathrm{~mm}$.

Figure 3 Ennucula ?aff. grayi (d'Orbigny). Sample $272-25-2,63 \mathrm{~cm} .21 \times 20 \mathrm{~mm}$.

Figure $4 \quad$ Malletia aff. subaequalis Sowerby. Sample 270-17-3, 95-100 cm. Two valves on broken face of core, cut by saw. $30.5 \times 16.6$ and 25 $\times 13 \mathrm{~mm}$.

Figure $5 \quad$ Malletia aff. subaequalis Sowerby. Sample 270-16-4, 100-104 cm. $24 \times 13 \mathrm{~mm}$.

Figure $6 \quad$ Chlamys (s. l.) n. sp. aff. natans (Philippi). Sample 272-33-2 (top). $31 \times 25.7 \mathrm{~mm}$. Mold of left valve exterior.

Figure 7 Periploma (Pendaloma?) n. sp. Sample $270-25-4,52-54 \mathrm{~cm} .15 \times 12.5 \mathrm{~mm}$. 
PLATE 1
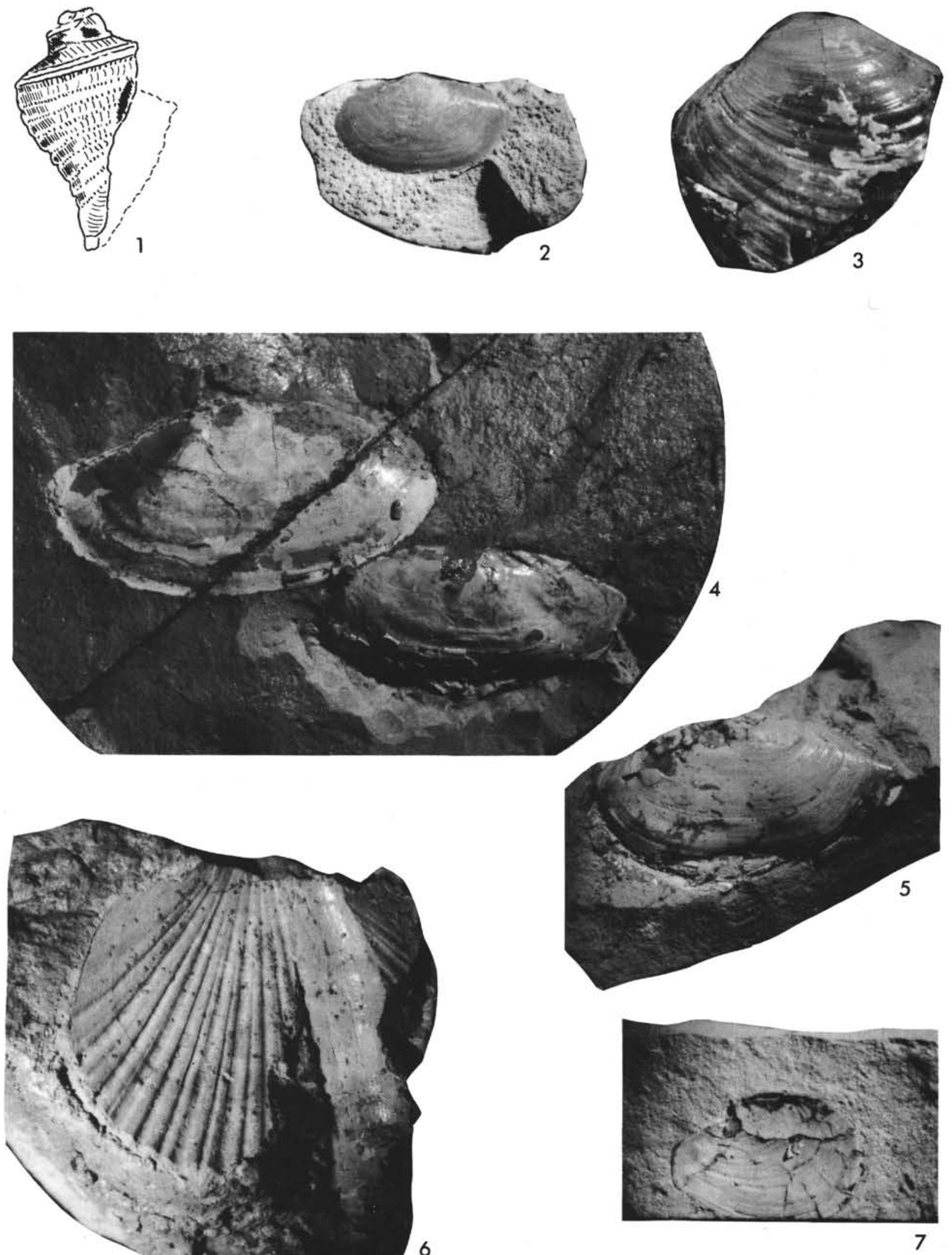